\title{
A Preliminary Study of Strategic Competitiveness of MDF Industry in Peninsular Malaysia by Using SWOT Analysis
}

\author{
Mohd Shahwahid Hj. Othman \\ Department of Hospitality \& Recreation, Faculty of Economics \& Management \\ Universiti Putra Malaysia, 43400 Serdang, Selangor, Malaysia \\ E-mail: msho@econ.upm.edu.my \\ Abdul Rahim Abdul Samad \\ Department of Economics, Faculty of Economics \& Management \\ Universiti Putra Malaysia, 43400 Serdang, Selangor, Malaysia \\ E-mail: abrahim@econ.upm.edu.my
}

The research is financed by the Yayasan Pak Rashid (YPR) research grant 2008, Universiti Putra Malaysia, Malaysia.

\begin{abstract}
Within three decades, the medium density fibreboard (MDF) industry has grown and contributed significantly to the external trade of the wood-based sector of Malaysia. However, at present, the industry is at a cross road. Although in Peninsular Malaysia MDF trade is expanding, but initial relative advantages over other competitors have marginally eroded. Over time new critical success factors played important roles as the industry responded to changes in global challenges. Through an industrial survey using the strength, weakness, opportunity and threat (SWOT) approach, this paper assesses only these four elements as a preliminary study for further analysis in analysing the strategic competitiveness and core competencies of MDF industry.
\end{abstract}

Keywords: Medium density fibreboard (MDF), SWOT analysis, Preliminary study

\section{Introduction}

The development of the MDF industry in Malaysia started in 1987 but has since rapidly developed to nine plants, eight of which is in the peninsula. The production, consumption, export and import status of MDF in Malaysia is provided in Table 1. Most plants used rubberwood as their major raw material. Projections show that in the near future the supply of rubberwood will not meet the demand by MDF plants (Ismariah \& Norini, 1994). One of the possibilities in overcoming this problem is to embark on intensive forest plantation programme. Effective utilisation of fast-growing non-wood lignocelluloses materials and agro-wastes has been of great interest due to a drastic fall in forest resource. MDF made from oil palm fibres and kenaf have been widely studied and developed.

The need for a forest plantation programme has long been recognised as an important move to supplement the supply of timber in Malaysia. To supplement the supply of raw material from natural forests for the expanding timber industry, the Government of Malaysia, through the Ministry of Plantation Industries and Commodities (MPIC), has initiated the establishment of commercial forest plantations. The target of MPIC is to plant 375,000 hectares of forest plantation within a 15-year cycle to ensure the sustainable growth of the timber sector and to continue to contribute towards the growth and development of Malaysia's economy. The government has allocated RM200 million in the form of soft loans for financing the forest plantation establishment from 2006 to 2008. Eight fast growing timber species have been identified as being suitable for the forest plantation programme including Rubberwood (Hevea brasiliensis) Acacia Hybrid (Acacia spp.) Teak (Tectona grandis), Sentang (Azadirachta excelsa), African Mahogany (Khaya ivorensis), Binuang (Octomeles sumatrana), and Kelempayan (Neolamarckia cadamba). 


\subsection{Strategic Competitiveness Assessment}

From the above review, producers need to understand these changes to take advantage of the opportunities these present for production, investment and trade, and their impacts upon the competitiveness. They have to anticipate and response by planning effectively. Planning provides three primary benefits: (i) the identification of future opportunities, (ii) anticipation and avoidance of future problems, and (iii) the development of strategies and tactical actions (Anon, 2007). The development of feasible alternative strategies depends to a large extent on the ability of the producer to examine its internal and external environments and to identify its competitive strengths and weaknesses, potential opportunities and threats to its business. Figure 1, shows a simple process of strategic competitiveness assessment. The assessment involves conducting an internal and external analysis facing the industry concerned. A stock taking of the capabilities and unique competencies existing in the industry has to be undertaken. The gaps that exist in the internal and external environments together with information on the capabilities and core competencies would allow the industry to identify critical strategies and tactical actions to take advantage and to overcome impediments faced. The focus is on business-level planning rather than corporate-level or functional-level planning. The arrows indicate the primary sequence of planning tasks. In practice, the sequence is neither purely systematic nor one-way as the two-way arrows suggest.

Assessing strategic competitiveness is widely researched in the developed countries, but documentation of research on this topic for the wood-based sector in Malaysia is still wanting. Some of the related studies on strategic planning among Malaysian businesses include that on the food industry (Md. Zabid et al., 1988), agrobased industries (Zainal Abidin, 1988), insurance industry (Md. Zabid et al., 1991), furniture industry (Mohd Shahwahid et al., 1995), education industry (Ismail et al., 2007) and international information system of multi-national firms (Mohdzaher \& Ward, 2007). Owing to the regional transformation happening in the composite board industry, there is a need to conduct a strategic competitiveness analysis of the industry in Malaysia.

\subsection{Objective of Study}

Given the above issues and competitive situation facing the MDF industry, it is necessary for the industry to take stock of its strategic position and reassess its performance. In particular, the industry has to re-evaluate its comparative advantage, constraint and state of competitiveness. This paper seeks to conduct a preliminary study of MDF industry by using SWOT analysis as a foundation to conduct the strategic assessment of the competitiveness of MDF industry in Peninsular Malaysia. This will base on the objective of understanding and analysing its reactions toward issues and challenges being faced.

\section{Methodology}

The method applicable in strategic analysis are numerous, both quantitative and qualitative, either based on time series or expert panels. Apparently the most common practical analytical tool for strategic planning is the SWOT analysis (Thompson \& Strickland, 1999). The core of this procedure is to identify the content of all four elements of the matrix. It was originally meant for evaluation of business corporations or profit centers. According to Thompson \& Strickland (1999), a SWOT analysis enables an industry to understand its overall business environment. The information gained from a structured and well documented industry analysis can help support key decisions made in all areas across an organization, whether it is sales, marketing, business development, operations, technology or even human resources. In order to remain competitive in the marketplace, an organisation needs to understand the various components and drivers of the industry in which they compete. While the identification of capabilities and core competencies enable the industry to identify and understand the potential opportunities and constraints that exist in the organisation. It is then possible to make informed strategic choices and plan about the future of the organisation.

The SWOT analysis has been adopted in assessing the strategic performance of selected wood based industries including in overall forest industries by (Korpela et al., 2001) and in furniture by (Mohd Shahwahid et al., 1995).

To conduct the above research tasks, seven out of the eight firms from Peninsular Malaysia were surveyed and interviewed guided by a questionnaire in mid-2008. A questionnaire was frame and pre-tested with one of the firm in the industry after which further modification was made. Hence, the final questionnaire used in this study was developed based on the literature on strategic planning as well as after obtaining feedback from the industry. The questionnaire is composed of inquiries on;

a. The strengths or advantages endowed within the firms. These elements are within the control of the firm management.

b. The weaknesses or disadvantages faced within the firms. These elements are also within the control of the firm management.

c. The opportunities that exist in the business environment that the firm could take advantage. These openings are not under the control of the firm management. 
d. The threats that exist in the business environment that the firm would have to overcome. These challenges are not under the control of the firm management.

e. The identification of capabilities and unique competencies available within each firm that contribute to the survivality and competitiveness of the firm.

f. The strategies and actions undertaken by each firm to capitalise on its strengths and opportunities, and to overcome on its weaknesses and threats facing the firm. The relationships of these strategies and actions on the firm's capabilities and core-competencies are traced.

\section{Findings}

\section{Strengths}

Raw material supplies are procured by three means namely;

a. $\quad$ Long term forest plantation concession

b. $\quad$ Long term contract with raw material contractors involving $28.5 \%$ of the plants.

c. Monthly raw material agents

Long term agreement concessions are obtained by MDF plants at Acacia forest plantations in Rawang, Selangor. Only $28.5 \%$ of the plants in the industry have these concessions (Table 2). The concession involved 12,000 acres over 7 years lease. $14.2 \%$ of the plants adopted an alternative long term supply arrangement by entering into a long term contract with wood supply contractors who have an arrangement with the Ulu Sedili Acacia forest plantation concessionaire. This involved 56,000 acres for 5 years.

For the above plants concerned, these long term forest plantation concessions and contract are essential for wood material stability. These plants have the comparative advantage over other plants in steady raw material supplies, continuity of plant production capacity utilisation and long term business planning. Another $28.5 \%$ of the MDF plants assure themselves of raw materials by having regular monthly quantity supplies from dedicated and reliable independent wood supplying agents. The rest of the plants (57.2\%) have less regular and reliable wood material supplier.

The location of MDF plants vis-à-vis the raw material sites has an influence on production cost due to differences in the cost of transporting the raw material. Plants located in the north and the south of the peninsula faced less competition for wood raw material supplies unlike those located in the central region. Hence, plants in the northern and southern regions tend to have supplies from within $50 \mathrm{~km}$ radius. $71.5 \%$ of the total number of plants fall in this category while the rests have to source their wood material further than $50 \mathrm{~km}$ radius. For those log sources within $50 \mathrm{~km}$ radius, there is a transportation cost saving. For instance, transportation cost within $50 \mathrm{~km}$ radius of the plant at Kulim is only RM15-20/mt while for distances between $50 \mathrm{~km}$ to $150 \mathrm{~km}$ the transportation cost ranges from RM20-RM30/mt (Table 2).

A distinct strength of the MDF industry is the strong financial support received by the plants from their private owners $(71.5 \%)$ and the public listed company management board (14.3\%). These plants have received full support for further investment in production expansion and technology modifications. For instance, one plant is wholly owned by a financial company hence, its investment activities are fully financed by its own equity without external borrowing. Others make investments supported by finances from their foreign equity partners/owners.

Continuous production technology innovation, and research and development (R\&D) are very essential drivers sustaining competitiveness in high technology industries. The MDF plants in the country have been established since the eighties and many experiences have been gained in production technology innovation. These together with the ease of owners and partners financial support have enable investments in plant improvement activities for raising production efficiencies. $100 \%$ of the plants are producing at $126 \%-150 \%$ of their technical capacities. One of the plants accounted this performance to their efforts at press modification to overcome its normal production bottleneck involving an additional expenditure of RM4.4 million on press machinery and RM1.5 million on pre-heater as well as in investing on computer system and plant management.

Inadvertently, the above efforts provided other advantages;

i) Plants are able to keep low production rejection rate. $100 \%$ of plants are able to keep the rejection rate below than $2.5 \%$. It is interesting to note that this performance matches the international benchmark production rejection rate. One plant accounted this performance to the investment made on a drum debarker to get rid of latex as well as on shifters to rid off the remaining rubber in the fibres. This resulted in rejection rates due to rubber spot to below $1 \%$.

ii) Plants are able to lower their production down time to a minimum. The majority of the plants are able to keep production down time to less or equal to $10 \%$. Experience productions engineers are able to troubleshoot and diagnose the problematic production activities. However, another $14.3 \%$ are able to keep their down time in the range of 
$11 \%-20 \%$ but this is a temporary situation since the plant is involved in a rationalisation process involving its acquisition by a bigger cash strap concern.

iii) Plants are able to raise their line speed which is a measurement of the press factor that provides the speed of production that would directly affect the level of productivity. $85.7 \%$ of MDF plants are able to achieve a line speed of below $7 \mathrm{~second} / \mathrm{mm}$ for $12 \mathrm{~mm}$ board while the rest achieve a line speed by $8-10 \mathrm{~second} / \mathrm{mm}$.

Direct participation of management at major production operation activities could enhance an ambience of experience sharing while reducing bottlenecks in major improvement decisions. This would allow for direct knowledge and guidance of operational constraints and problems faced at the production level. However, this will only happen if management is not involved in petty and minor operational decision making. All MDF plants have the benefits of the active participation in production operations by management. Hence, the above productivity achievement reported earlier is also contributed by this influence.

All MDF plants in the country have the ability to retain their skill workers. There are many contributory reasons. One plant has attributed this to its human resource remunerative package of providing a clear career path and training opportunities, as part of its adoption of the concept of "gemba kaizen" (workplace continuous improvement concept). Several others relate their productivity incentive scheme as an important factor. For example, if the production exceeding the predetermined targets, workers would be rewarded. In some plants, a worker could obtain on average a productivity reward of RM150-RM600/month or RM2,000/year.

To ensure continuous running of the production line, plants would have to avoid long downtime periods. An important consideration is the availability of critical spare parts. $71.4 \%$ of the MDF plants have the foresight to maintain stocks of critical spare parts. For instance, two plants maintain a stock of RM18 to RM20 million spare parts, including of main motor, press steel belt, sanding belt, refiner feeding screw and casing. Such a stock assures the plant's readiness for potential breakdown with little downtime.

\subsection{Weaknesses}

Previously Malaysia was known for its relatively homogenous rubberwood MDF board. Malaysian MDF plants are no longer able to procure $100 \%$ rubber wood materials, hence affecting their ability to produce homogeneous pale boards. Ever since the shortages of rubberwood logs, Malaysian MDF plants have to utilise a combination of wood materials (Table 3). In 2008 on average MDF plants are utilising 40\% Acacia (25\% Acacia slabs-price at RM50/mt and another 15\% Acacia log-at greater than RM100/mt), 20\% mixed hardwood log and slabs (price RM80/mt), and the rest are taken up by rubber log (RM120/mt). Cost of mixed hardwood logs is high and more glue is needed in board production then when using rubberwood, yet a producer has to sell the hardwood MDF board at almost the same price as rubberwood MDF boards. As a result, this would reduce the profit.

Popular orders for MDF boards are in $4 \mathrm{ft}$ by $8 \mathrm{ft}$ board measurement. Despite rising demand for MDF, not all Malaysian plants could take advantage of this situation because of the design of their production lines. $85.7 \%$ of the MDF plants have their second production lines that are not $4 \mathrm{ft}$ by $8 \mathrm{ft}$ board size (Table 3 ). Instead these production lines are on $3 \mathrm{ft}$ by $7 \mathrm{ft}$ board size. Hence, these plants may not be able to fulfill rising demand for the high orders of the conventional $4 \mathrm{ft}$ by $8 \mathrm{ft}$ board size. However, since all plants are now operating in excess of their technical capacity, this constraint is not a major limitation.

An important tenet in marketing is the ability to meet customer needs such as board size and board thicknesses. A majority of the MDF plants could manoeuvre their production line to a range of board thicknesses from $3 \mathrm{~mm}$ to $25 \mathrm{~mm}$. Only $14.3 \%$ of the plants interviewed have difficulty in meeting the thickness requirements of customers at short notice. The difficulty occurs at the press machine involving pressure and temperature adjustments. Hence, these plants could not take advantage of varied board size and small quantity orders.

The production costs for MDF are rising in Peninsular Malaysia at a rate of $6 \%$ per annum. This occurs due to the plants facing stiff prices for all their major inputs that include rising prices of raw materials $(20 \%$ per annum during the period 1990-2006), and glue (33\% per annum). Raw material takes up a large proportion of production cost. The inability to manage these cost components would raise Malaysian MDF prices relative to competing international producers and may jeopardize Malaysian global market share. Plants would have to look at potential sources of cost reductions since wood material price increments are imminent.

\subsection{Opportunities}

International markets demand for MDF boards comprise of multiple dimensions. The largest market is for homogenous lighter boards and thick boards $(>6 \mathrm{~mm})$. There are also specific niche markets for more heterogenous darker boards, 'green' (E0) boards and thin boards $(<6 \mathrm{~mm})$. In general, the market mix for MDF boards are $8.3 \%$ for E0 boards, $62.5 \%$ for light and thick boards, $20.9 \%$ for darker boards and $8.3 \%$ for thin boards. 
Owing to difficulty of procuring only rubberwood or Acacia logs, there is a cost advantage of utilising mixed tropical sawmill wastes and off-cuts which are priced relatively lower. Hence, cost of production would be lowered with a little trade off on quality. There are markets that prefer lower quality (heterogeneous and darker) boards and prices. There is an opportunity for such niche market. $14.3 \%$ of MDF plants are capitalising on this niche market by developing new geographical destinations successfully. Mixed hardwood MDF boards are now being exported to India and Sri Lanka by Robin Group (Robin, 2007).

There is an international demand for thin boards. Table 4 shows that, $14.3 \%$ of MDF plants have a production capacity for thin boards (less than $6 \mathrm{~mm}$.) Thin board fetches higher prices than thicker board by as much as $50 \%$, creating more value for the producer. Over several decades of trial and error experimenting with its production line, this plant was able to fine-tune its press profile in its production line to cater for thin board manufacturing. Although the market is relatively small, there is an opportunity to specialise in this market segment. This plant is producing thin boards in response to consumer needs and high competition for thick boards. The majority of MDF plants produced thick boards and there is less competition by producing thin boards. This plant started manufacturing $100 \%$ thin boards using their two production lines since 2006. Prior to this, the production base between thick and thin boards was 50:50. There is another plant that is manufacturing both thick and thin boards in equal proportions. The popular market destination for thin boards is Japan where there is a preference for lighter boards in their kitchen and bedroom cabinets and interior decorations. Additionally, the endurance of thin board was design as strong as thick board.

With the greater global consciousness on lower emission of formaldehyde from boards, there is a growing market for environmental friendly E0 MDF boards, particularly in Japanese market. Although the market is relatively small, but there is a high price premium (10\%) attached to such boards. Hume Fibreboard is actively involved in the manufacturing of E0 boards taking up 15\% of their production base (Hume, 2007).

With the decline in supply and rising prices of rubber and Acacia logs, plants are now experimenting with alternative materials like forest residues, new crops (kenaf) and agricultural waste such as oil palm trunk, fronds and empty fruit bunches in the move to find complementary wood materials and as replacements. $42.8 \%$ of the MDF plants are now investing in $\mathrm{R} \& \mathrm{D}$ efforts and collaborating with universities and research institutes with materials like kenaf (with Universiti Putra Malaysia) and oil palm fronds and empty fruit bunches (with Malaysia Palm Oil Board) with a focus to determine optimum combinations between these alternative materials and rubber logs. Preliminary findings from this $\mathrm{R} \& \mathrm{D}$ effort have been promising (Harmaen et al., 2007).

The Malaysian government has allocated soft loans for financing of forest plantations. This is an opportunity for MDF plant to integrate vertically into investing in upstream investment for supplying wood material. This could facilitate long term log material security. However, based on feedbacks, none of MDF plant has been awarded this allocation. Apart from the above special loan scheme, the Malaysian government also provides fiscal and financial incentive such as Pioneer status (5 years), double tax exemption on spare part from Malaysia Industrial Development Authority (MIDA) and R\&D expenditure as well as export promotion activities. Majority of the MDF plants are taking advantage of this incentive package.

Recent development in forest plantation in Peninsular Malaysia has seen the privatisation of major forest plantation areas in Ulu Sedili, Johore, Kemasul, Pahang and Rawang, Selangor into smaller long term concessions. Although, many of the successful concessionaires are non-wood-based manufacturing concerns, $28.6 \%$ of the MDF plants were able to acquire strategic interests in 12,000 acres of the Rawang forest plantation. This is an opportunity for these plants to stabilise their long term wood material supplies.

Ever since 2004 with the reintroduction of the floating exchange rate, the Ringgit Malaysia (RM) has steadily been appreciating against the U.S. Dollar (USD). An appreciation in RM against USD has made repayment of imported plants and machinery cheaper. This involves $28.5 \%$ of the plants who have invested in refurbishment of their production lines and are now benefiting from the RM appreciation (Table 4).

\subsection{Threats}

Logistic affects procurement cost for raw materials. Ideally, plants would prefer to source their wood materials from contiguous tree holdings, which would cut down on delivery costs. However, $89 \%$ of rubber trees are planted in smallholdings with the rest in larger scale estates (Table 5). This situation is made worst by the irregular ages of the tree stands in smallholdings, hence replanting programs during which moribund trees are felled, are being scheduled at different time periods. Further, supplies from a smallholding do not have the economies of scale over estates. The average land area of smallholdings is about two ha (RISDA, 2007).

Owing to wood material shortage, MDF plants are facing intense competitions and a price war on rubberwood material among themselves. This is affecting particularly $71.4 \%$ of the plants especially when they do not own forest plantation concession (Table 5). There is no long term contract in the supply of raw wood material by independent suppliers and 
agents. These suppliers sell to the highest bidder among the MDF plants. Hence, in order to secure monthly wood supplies, plants tend to outbid each other. This leads to a rising trend in wood material prices.

In 2007, 35\% of rubber areas have been converted to alternative crops and for development purposes (Table 5). Of these rubber areas, $25 \%$ are being converted to oil palm which yielded higher monetary returns, $5 \%$ to other crops including fruit trees, and another $5 \%$ have been developed into building and infrastructural projects. When these tree crops mature, there would be a decline in the long term supplies of rubber logs from estates and smallholdings.

Latex prices have been buoyant in the last couple of years since 2002. Latex prices have gone up from RM3.50/kg in 2002 harbouring at around RM5.50/kg to RM7.50/kg in 2007 (RISDA, 2007). Rising latex prices can influence rubber log supplies by delaying the motivations of rubber smallholders and estate owners to replant their moribund trees. An interview of thirty Rubber Industry Smallholders Development Authority (RISDA) district officers, suggested that $30 \%-40 \%$ of rubber smallholdings have delayed felling matured rubber trees for replanting activities in order to continue extracting latex, even though the trees have reached the moribund stage of the latex production cycle. This delay in replanting has created a shortage of rubberwood supply, leading to an upward pressure on domestic rubber log prices in the last few years.

For long term security of wood materials, it is advantages for plants to establish forest plantations. $57.1 \%$ of MDF plants are facing difficulties to establish plantation due to unavailability of land in substantial area to obtain economies of scale (Table 5). Only $28.6 \%$ of MDF plants were able to obtain concession rights over 4,860 ha of Acacia forest plantation at Rawang, Selangor. Further, all of the MDF plants in Peninsular Malaysia were not given priority in soft loan scheme under the government forest plantation program.

Malaysian workers have a preference for cleaner and conducive work environment like in electrical appliances factories in comparison to wood based mills. Hence, all MDF plants are facing competition for local workers from none wood based mills. MDF plants suffer this predicament and have to rely on imported labor. Relying on foreign labor is not without its problems. Foreign workers have work permits of up to two years, and renewable four times up to ten years. After which they would not be renewed. The majority of these foreign workers who are fully skill by that time would be an asset to their potentially new employers in competing countries. This action in itself is tantamount to exporting skill labor and in inviting competitions to Malaysian manufacturers.

The growing domestic demand for MDF in the downstream wood based industries is another market expansion opportunities for the MDF plants. But with the growth of the Chinese MDF industry, exports into Malaysian from China are creating stiff competition to domestic MDF plants (Table 5). Nevertheless, MDF plants in China are facing excess capacities owing to insufficient raw materials.

In the international market, China is now a growing giant. Statistics show that there were nearly 40 MDF plants in China manufacturing $589,000 \mathrm{~m}^{3}$ in 1995 . Of which, there was only one plant with an annual productive capacity of $100,000 \mathrm{~m}^{3}$, two plants $50,000 \mathrm{~m}^{3}, 11$ plants $30,000 \mathrm{~m}^{3}$, and most of the remaining plants around $15,000-20,000 \mathrm{~m}^{3}$. But by 2005 , Chinese MDF production capacities have increase to 2,900,000 $\mathrm{m}^{3}$. Similarly, exports have change drastically from $7,000 \mathrm{~m}^{3}$ to $200,000 \mathrm{~m}^{3}$ respectively (FAO, 2005). One of the reasons for this rapid growth is the opening of China to international investors that has led to a proliferation of MDF plants in China. The Chinese economy is characteristically efficient in labor and capital utilisation minimising production cost. Hence, MDF manufactured in China is very competitive in the market.

The appreciation of Ringgit exchange rates against the USD also acts negatively against Malaysian manufacturers by reducing profit margin on committed orders negotiated when the USD was stronger. This is disadvantages to Malaysia suppliers. Unless firms practice hedging or renegotiate contracted prices.

\section{Conclusion}

This paper has conducted a preliminary study of MDF industry in Peninsular Malaysia by using SWOT analysis. Hence, we found clear results of strengths, weaknesses, opportunities and threats of this MDF industry. From these results, it will then be used as a foundation to identify the strategic actions plan and core competencies for the extension of this study. Central to competitiveness of the industry is the looming decline in rubberwood supplies and rising input prices. The MDF plants have responded in several four elements of the SWOT analysis. From 2007 till present this industry are having a merger of a number of plants and investing in production line improvements, manufacturing of glue, power generation and forest plantations. Plants have taken advantage of niche market opportunities by turning raw material constraints to advantages, in raising production of thinner boards and environmentally friendly boards. R\&D on alternative wood materials and product development has also been given emphasis. As regards of the extension of this study, we intend to come out with several core competencies and strategic action plans that can be used to sustain this industry. 


\section{References}

Anon. (2007). Timber Market Brief. Volume 149/May 2007.

FAO. (2005). FAOSTAT database. FAO, Rome.

Harmaen, A.S., Jalaluddin, H., Paridah, MD.T. \& Nor Yuziah, M.Y. (2007). Properties of medium density fibreboard (MDF) admixture rubber tree RRIM 2020 clone fibres and oil palm empty fruit bunch (EFB) fibres blends. Paper presented at the $7^{\text {th }}$ National Conference on Oil Palm Tree Utilisation. 13-15 November 2007, Sunway Resort Hotel and SPA, Bandar Sunway, Petaling Jaya, Selangor.

Hume. (2007). News and Information. [Online] Available: http://www.humewood.com.my/eng/news.htm

Ismail, N.A., Ali, R.H.R.M. \& Hisbollah, H.M. (2007). Strategic information systems planning in Malaysian public universities. Campus-Wide Information Systems, 24 (5), 331-341.

Ismariah, A. \& Norini, H. (1994). Rubberwood: Processing and Utilization-Availability of rubberwood Resource in Peninsular Malaysia-Compiled using from Dept. of Statistics, FELDA, RISDA and FELCRA. FRIM Malaya Forest Record No. 39, pp. 247.

Korpela, J., Sierila, P. \& Tuominen, M. (2001). A GDSS-based approach to the strategy analysis of forest industries. Proceeding of the $34^{\text {th }}$ Hawaii International Conference on System Sciences. 10-13 December 2001, Finland.

MD Zabid, A.R., Samsinar, M.S., Badriyah, M. \& Mohd. Mansor, I. (1988). Planning Characteristics of Small Firms in Malaysia. Department of Management Studies, FEP, UPM, DEC., Staff Paper NO. 17:24.

Md. Zabid, A.R., Kamaruddin, S., Maisom, O. \& Roslan, A.G. (1991). Strategic planning in the Malaysian insurance industry. The Geneva Paper on Risks ans Insurance, 16, 448-461.

Mohd NOR, M.Y., Mohd. Zin, J. \& Wan Roshdan. (1993). Characteristic of MDF made from admixture of oil palm frond and rubberwood fibres. Paper presented at The National Seminar: Utilization of Oil Palm Tree and Other Palms. $\left(3^{\text {rd }}: 1994:\right.$ K.L $)$.

Mohd Shahwahid, H.O., Saroni, J. \& Salleh, Y. (1995). Element of strategic planning among Malaysian furniture manufacturer. Journal of Tropical Forest Product, 1(2), 162-179.

Mohdzaher, Mohdzain \& Ward, J. M. (2007). A study of subsidiaries' views of information systems strategic planning in multinational organizations. Journal of Strategic Information Systems, 16, 324-352.

RISDA. (2007). Rubber information and statistic. [Online] Available: http://www.risda.gov.my

ROBIN. (2007). News and information. [Online] Available: http:// www.robinmdf.com/Production.htm

Thompson \& Strickland. (1999). Strategic management, $11^{\text {th }}$ edition. McGraw-Hill Book Company, New York.

Table 1. Production, consumption, export and import status of MDF in Malaysia (' $000 \mathrm{~m}^{3}$ )

\begin{tabular}{|c|c|c|c|c|}
\hline Year/Item & 1995 & 2000 & 2005 & $2010^{*}$ \\
\hline Production & 350 & 1000 & 1500 & 2000 \\
\hline Consumption & 100 & 180 & 290 & 417 \\
\hline Export & 250 & 820 & 1210 & 1583 \\
\hline Import & 0 & 0 & 0 & 0 \\
\hline
\end{tabular}

* Projected

Source: FAO 2005 
Table 2. Strengths existing in the MDF plants of Peninsular Malaysia

\begin{tabular}{|c|c|c|}
\hline & Factors & $\begin{array}{l}\text { Average } \\
\text { Percentage* }\end{array}$ \\
\hline 1 & $\begin{array}{l}\text { Stable raw material supplies: } \\
\text { - Long term agreement forest } \\
\text { plantation concession } \\
\text { - Long term contract supplies with forest plantation concession } \\
\text { - Reliable and loyal independent raw material supplies/agent }\end{array}$ & $\begin{array}{l}42.8 \% \\
28.5 \% \\
28.5 \%\end{array}$ \\
\hline 2 & $\begin{array}{l}\text { Strategic location to raw material supplies: } \\
\text { - Raw material located with in } 50 \mathrm{~km} \text { radius of plant } \\
\text { - Raw material located between } 51-150 \mathrm{~km}\end{array}$ & $\begin{array}{l}71.5 \% \\
28.5 \%\end{array}$ \\
\hline 3 & $\begin{array}{l}\text { Strong financial support: } \\
\text { Financial backing from private owner } \\
\text { Financial resources provided by public listed company }\end{array}$ & $\begin{array}{l}85.8 \%: \\
71.5 \% \\
28.5 \%\end{array}$ \\
\hline 4 & High production technology innovation & $85 \%$ \\
\hline 4.1 & $\begin{array}{l}\text { Production at; } \\
100-125 \% \text { technical capacities } \\
126-150 \% \text { technical capacities }\end{array}$ & $\begin{array}{l}0 \% \\
100 \%\end{array}$ \\
\hline 4.2 & $\begin{array}{l}\text { Production rejection rate; } \\
\text { less than } 2.5 \% \\
2.6 \%-5 \%\end{array}$ & $\begin{array}{l}100 \% \\
0 \%\end{array}$ \\
\hline 4.3 & $\begin{array}{l}\text { Production down time; } \\
\leq 10 \% \\
11-20 \%\end{array}$ & $\begin{array}{l}85.7 \% \\
14.3 \%\end{array}$ \\
\hline 4.4 & $\begin{array}{l}\text { Line speed/press factor }(12 \mathrm{~mm}) \\
5-7 \mathrm{sec} / \mathrm{mm} \\
8-10 \mathrm{sec} / \mathrm{mm}\end{array}$ & $\begin{array}{l}85.7 \% \\
14.3 \%\end{array}$ \\
\hline 5 & High participation of Management in major production operations & $100 \%$ \\
\hline 6 & $\begin{array}{l}\text { Plant improvement investments together with intensive guidance by corporate } \\
\text { procedures }\end{array}$ & $100 \%$ \\
\hline 7 & $\begin{array}{l}\text { Ability to retain skill manpower due to: } \\
\text { - Continuous work place improvement } \\
\text { - Human resource remunerative package }\end{array}$ & $\begin{array}{l}100 \% \\
100 \% \\
100 \%\end{array}$ \\
\hline 8 & Availability of stocks of critical spare parts & $71.4 \%$ \\
\hline
\end{tabular}

* Frequencies computed from field survey data most plants have several alternative sources of raw materials at any time.

Note: The $42.8 \%$ of the plants having forest plantations also rely upon the other sources to obtain their plants full raw material requirements. But $57.2 \%$ of these plants do not have regular and reliable wood supply agents 
Table 3. Weaknesses existing in the MDF plants of Peninsular Malaysia

\begin{tabular}{|l|l|l|}
\hline & Factors & Average Percentage* \\
\hline 1 & $\begin{array}{l}\text { Inability to procure rubber wood materials is jeopardising single species } \\
\text { pale board production }\end{array}$ & $100 \%$ \\
\hline 2 & Second production lines that are not 4ft by 8ft board size & $87.5 \%$ \\
\hline 3 & Marketing directed by size and thickness availability & $14.3 \%$ \\
\hline 4 & Rising production cost affecting profitability & $100 \%$ \\
\hline
\end{tabular}

Frequencies computed from field survey data

Table 4. Opportunities existing in the MDF plants of Peninsular Malaysia

\begin{tabular}{|l|l|l|}
\hline & Factors & Average Percentage* \\
\hline 1 & $\begin{array}{l}\text { Niche markets according to each plant production advantages - plants using } \\
\text { mixed hardwood slabs and off cuts focusing into India and Sri Lanka. }\end{array}$ & $14.3 \%$ \\
\hline 2 & $\begin{array}{l}\text { Niche market prospects } \\
- \text { for specific markets demanding heterogenous boards } \\
- \text { for specific thickness: thin boards }(<6 \mathrm{~mm}) \\
- \text { for green boards (E0) }\end{array}$ & $\begin{array}{l}14.3 \% \\
28.6 \%\end{array}$ \\
\hline 3 & Availability of alternative raw material enable R\&D innovation & $28.6 \%$ \\
\hline 4 & $\begin{array}{l}\text { Government incentive in: } \\
\text { forest plantation establishment soft loans }\end{array}$ & $42.8 \%$ \\
\hline 5 & fiscal and financial incentive & $0 \%$ \\
\hline 6 & $\begin{array}{l}\text { Appreciation in RM against USD has made repayment of imported plant } \\
\text { and machinery cheaper. }\end{array}$ & $28.5 \%$ \\
\hline
\end{tabular}

Frequencies computed from field survey data 
Table 5. Threats facing in the MDF plants of Peninsular Malaysia

\begin{tabular}{|c|c|c|}
\hline & Factors & $\begin{array}{l}\text { Average } \\
\text { Percentage* }\end{array}$ \\
\hline 1 & $\begin{array}{l}\text { Rubber log material supplies base is not contiguous because comprise of: } \\
\text { Smallholdings ( } \% \text { of rubber areas }) \\
\text { Estate }(\% \text { of rubber areas })\end{array}$ & $\begin{array}{l}89 \% \\
11 \%\end{array}$ \\
\hline 2 & $\begin{array}{l}\text { Intense competition for wood material among MDF plants within the same regions } \\
\text { (\% of MDF plants) }\end{array}$ & $71.4 \%$ \\
\hline 3 & $\begin{array}{l}\text { Conversion of rubber areas to alternative use (\% of converted area): } \\
\text { - Oil palm plantations } \\
\text { - Other crops included fruits } \\
\text { - Building and infrastructural projects. }\end{array}$ & $\begin{array}{l}35 \% \\
25 \% \\
5 \% \\
5 \%\end{array}$ \\
\hline 4 & Rising latex prices causing replanting delays ( $\%$ of all rubber districts) & $100 \%$ \\
\hline 5 & $\begin{array}{l}\text { Difficulties in establishment of forest plantation due to: } \\
\text { - lack of land availability (\% of MDF plants) } \\
\text { - MDF firms not given priorities in long term forest plantation concession } \\
\text { - MDF plants not given priorities in soft loan scheme under the forest plantation } \\
\text { program. }\end{array}$ & $\begin{array}{l}57.1 \% \\
71.4 \% \\
100 \%\end{array}$ \\
\hline 6 & $\begin{array}{l}\text { MDF plants are facing competition for local workers from none wood based plants } \\
\text { (\% of plants) }\end{array}$ & $100 \%$ \\
\hline 7 & $\begin{array}{l}\text { MDF firms are facing intense competition in: } \\
\text { - domestic market from both local and international MDF } \\
\text { Companies } \\
\text { - international market from China }\end{array}$ & $\begin{array}{l}85.7 \% \\
100 \%\end{array}$ \\
\hline 8 & Appreciation in RM against USD is reducing profit margin on committed orders & $100 \%$ \\
\hline
\end{tabular}

Frequencies computed from field survey data

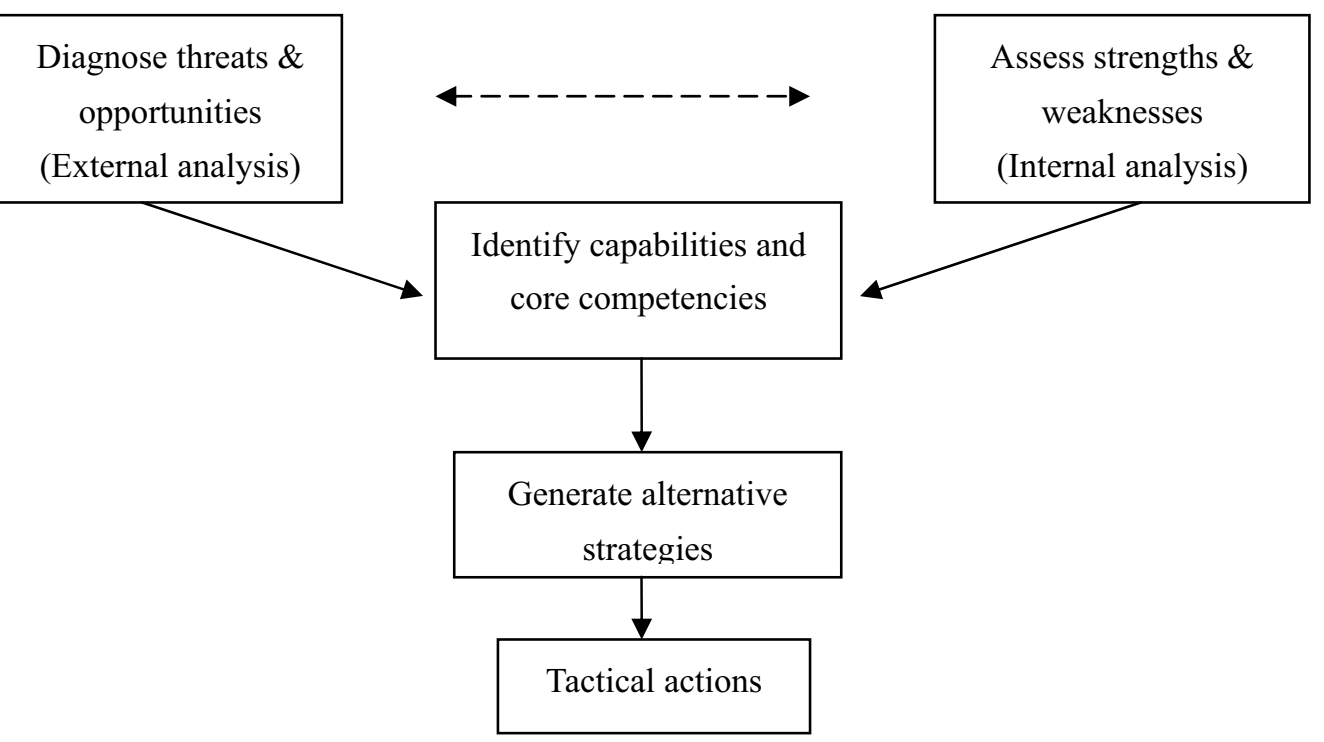

Figure 1. A Strategic Competitiveness Assessment 